\title{
ECOLOGICAL ECONOMICS - ABRIDGING THE GAP BETWEEN CONVENTIONAL ECONOMICS AND ETHICS
}

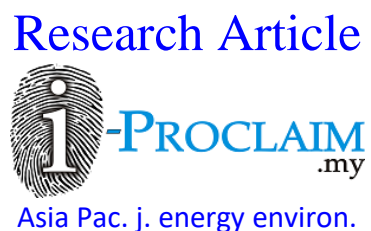

Asia Pac. j. energy environ.

\section{Mohammad Mokammel Karim Toufique ${ }^{1}$}

\author{
${ }^{1}$ Assistant Professor, Department of Economics, United International University, UIU Bhaban, Dhanmondi, Dhaka-1209, BANGLADESH \\ *Email for Correspondence: mktoufique@gmail.com
}

Abstract

\begin{abstract}
What role do ethics play in differentiating Ecological Economics from conventional Economics? How much ethical underpinning do various blazing environmental issues have? These are the question that this paper tries to answer. Conventional Economics focuses on the efficiency of resource allocation giving less weight to distribution and scale. But many economic problems have important ethical dimensions or implications. Mainstream economists have always ignored ethics as a key issue in economic theory. On the contrary, ecological economics argues that, in the face a severe environmental problem it is normal and natural for human beings to have concerns about the crisis and a healthy survival and to adopt a position of precautionary rationality. Ethics has important policy implications for market-based solutions, valuation, various environmental issues, the business world and its environmental responsibility, globalization, financial crisis etc. Ethics should not be analyzed in isolation of other factors affecting the economic phenomenon concerned. Future research should focus on how to formally incorporate ethics in standard economics model of various forms.
\end{abstract}

Key words

Ecological Economics, Economics, Ethics, Environment, Business

\section{INTRODUCTION - THE THEORETICAL IMPORTANCE}

Basic differences between environmental economics and ecological economics are that ecological economics emphasizes strong sustainability, rejects the idea of substitutability of natural capital for human-made capital. Also ecological economics questions many conventional economics methodology of valuation of nature as well as the cost benefit analysis. While the focus of the neoclassical economists is on the efficiency of resource allocation, ecological economics gives more weight to issues like distribution and scale. Additionally ecological economics makes a clear distinction between the qualitative and quantitative ameliorations of the quality of life. Ethical viewpoints take a center-place in the foundations of all those ideological arguments.

Most economics problems have underlying ethical aspects embedded in them. But conventional economics has not openly dealt those issues. As Van Staveren (2001) has explained - economics focuses on market (characterized by freedom) but disregards the mutual interdependence of freedom, care and justice. According to Rothschild (1993), though economic theory claims to be objective, they have many aspects, either explicitly or implicitly, that have ethical implications. Yeager (2001) holds the view that economics is sterile without ethics. Ecological economics came forward to a bridge the gap and went beyond by exploring new or hidden avenues. It has combined economics with philosophical expertise that was previously either missing or overlooked. Various contentious issues that involve the importance of equality, the extent of ecosystem preservation, valuing life/environment etc. are better understood when ethics take a relatively central stage.

The idea of 'rationality postulate' that says that "rational economic man maximizes his utility" is central to the neoclassical economics. Critics have pointed out that maximization may not be a feasible behavior, utility is unobserved and cannot be measured and rationality as defined by the neoclassical economists is devoid of sound ethical underpinnings. The mismatch between rationality and ethics has important bearings when analyzing and framing policies for various environmental issues. An alternative to neoclassical rationality is precautionary 
rationality which incorporates things like responsibility or sacrifice that are largely overlooked by neoclassical rationality. Though theoretically, if for an individual utility (which is value neutral) is the highest when he behaves ethically, ethics can be at the center of the utility function. But unfortunately, with the exception of Alfred Marshall and Amartya Sen, mainstream economists have always ignored ethics as a key issue in economic theory. On the contrary, ecological economics argues that, in the face a severe environmental problem it is normal and natural for human beings to have concerns about the crisis and a healthy survival and to adopt a position of precautionary rationality. A number of ethical positions like utilitarianism, justice as opportunity, ethic of sustainable development, religious traditions, stewardship/citizenship, traditional humanism etc are relevant to ecological economics (Krishnan et. al, 1995).

\section{Policy Significance}

\section{Ethics and market-based solutions}

Most economists think that ethical concerns should not and rightly do not interfere with market processes. They do not incorporate ethics while modeling economic behavior. But in reality, ethics and market are closely related and many market problems are inherently related to ethical issues. Though in this world of increasing scarcity, marketbased systems may be the only feasible option to apportion those scarce resources, in a society which is far from being the ideal one, market-based solutions are supposed to and they indeed do suffer from imperfections. And in the absence of proper monitoring, unbridled competition may lead to unfair practices that we have seen so many times.

\section{Ethics and valuation}

Valuation of natural resources would have been much different had ethics received the attention it deserved. Azquetaand Delacámara (2005) focuses on some ethical constraints to the traditional economic valuation methods to informed decision-making that affects the environment. They argue that environmental assets can be considered as a common heritage, not merely a pool of economic resource to fulfill basic needs and that would depend on the stage of development. Moreover, this boundary is not static - the same environmental asset can be treated (individually and socially) as resources (for depletion/transformed) at lower stages of development and a common heritage at a later stage. The conventional valuation methods would not be appropriate for the second case, whereas for the former case it can be.

\section{Ethics and environmental issues}

People have rights to a livable habitat, to health and to the normal functionality of life. The various aspects of environmental degradation generate huge blows to the enjoyment of those rights. Ethics actually has a major role to play in various contentious issues. For example, people should receive equal treatment/consideration is embedded in various policy issues that involve justice, fairness, rights - all the very familiar terms in various environmental problems. If we consider intergenerational issues of environmental risk sharing, ethics play a role here too. All individuals in all generations have equal right to life and hence without an adequate and just/fair compensation, one generation can't put individuals in other generations at a greater risk. Even when factors like merit, compensation or special needs are taken into account moral ground is always relevant. "Moral intuition tells us that our descendants deserve a world that we have tried to make better." Risks should be distributed equitably across generations. Efficiency itself doesn't guarantee an equitable distribution. Efficiency, economic expansion and utility have probably make inequities even worse. Most environmental policies, distribute the abatement costs in a regressive way and ability to pay often determines the associated risk and quality of life. As a result utilitarian risk distributions make political equality worse. As Brian Berry has pointed out, equal treatment of each generation requires that each generation has the same opportunity to use resources (oil, clean air/water/soil etc) like the other generations. Ethical responsibility can help a great deal in solving various problems of environmental injustices (Shrader-Frechette, 2002).

The environmental problems have usually affected the poor and the minorities of the society the most - not only because they are the poor and the minorities but also because the underlying value that the society has assigned to them are much lower compared to their counterparts of the rich and the majorities. But following moral philosophy, it's an ethically unacceptable way to gain at the expense of others.

The problem of climate change involves fundamental market-failure: parties responsible for the emission of greenhouse gas don't pay prices that reflect the damage. The underlying problem is inherently ethical one and according to Stern (2007) one of the basic criteria for global action to reduce greenhouse gas emission is equity (the other two being effectiveness and efficiency). 
Ethical level of a society is jointly determined by economic, social, religious as well as cultural/traditional characteristics. Often the causality may not be properly discernible as they all are very interdependent aspects of a society. In this era of globalization, at the formal level, ethical standards are continuously moving towards some kind of uniformity. This may have important implications for environmental policies across societies.

\section{Ethics, environmental responsibility and the business world}

The last decade has witnessed an impressive growth of corporate responsibility. In recent years increasingly higher number of international business leaders has shown interest and often have acknowledged and carried out their environmental responsibilities. Though this environmental sensitivity of corporations is largely due to the underlying link between sustainable financial investment and the environment (in the 1980s the insurance industry suffered badly because of environmental litigations and this forced them to design environmental friendly management practices), ethics does play a role here (the role of many voluntary organizations are of immense significance here). A stronger role of environmental ethics can only better ensure the biospherical stability. In 1996 the financial institutions introduced environmental risk rating.

The business ethics has three dimensions: international, national and meta-ethical. The last dimension lays the philosophical, religious, economics/political foundations of business ethics. As the moral or ethical life has become very complex, for business leaders it is important to have a clear idea of what is 'right' and 'wrong' or what is 'moral' and 'not moral'. Though government often comes forward to ensure certain level of ethical behavior, much is left to the businesses to act on their own. Also, the corporate world prefers self-regulation and voluntary compliance which is usually received with suspicion by outsiders. There are many international codes of conduct in action. But the codes of conduct are often too general and there is no effective means to enforce them. In many countries problems arise when national and multinational companies are not treated equally in the eyes of law. The power/wealth responsibility ratio, customary in foreign policy, is now being applied to many corporations.

\section{Relevance of ethics to the financial crisis}

Some considers the current financial crisis as a consequence of continuous violations of ethical standards in the previous years. Corporate responsibility required professional judgment and background scrutinization before giving credits. This problem indicates deeper institutional problems (greed, mismanagement, bad decisions/judgment, lack of transparency) directly or indirectly related to ethics. Sometimes organizational goals are set and pursued in a way that managements try to achieve them without thinking much about the ways to achieve the goals. As a result the management doesn't consider the long run feasibility or the sustainability of their financial decisions. In a survey by the World Economic Forum (it polled 130,000 people in France, Germany, India, Indonesia, Israel, Mexico, Saudi Arabia, South Africa, Turkey and the United States) two-thirds of the respondents considered the financial crisis as a crisis of ethics and values. Many considered politics being too much centered on growth and it is the high time for virtues like accountability, responsibility, integrity, fairness etc, to be put at the center. At a time when President Obama proposed tighter regulations for banks, the JPMorgan CEO received \$17 million as bonuses whereas the Goldman Sachs CEO received $\$ 9$ million. Though public were outraged, very few politicians criticized the move.

\section{Ethics, globalization and the invisible hand}

Stiglitz (2003) analyzes ethical aspects of globalization. Starting from the ethical premise that "all men are created equal..." he argued that in the way globalization has been shaped, developed countries have violated ethical norms. Economics has its limitations, Stiglitz argues, and it can't solve every problems. He says that economics was meant for efficiency issues, not for issues of social justice and it was the responsibility of the government and the political processes to address distributive issues. In the presence of market failure, individual maximizing self interest may not maximize the overall interest of the society and Adam smith's advice is misguided when market failure is there. According to Stiglitz market failures (which may result from unethical behavior) lead to unethical behavior.

\section{Religion, ethics and environment}

In many instances, for a particular society and for a particular community religion determines the ethical foundation of the society/community. Some authors (i.e. E.F. Schumacher) have blamed religions for being the cause of the faulty value systems that have generated the environmental crisis. However many have argued that religions are the sources of ecological values. For example, Islam discourages luxurious living and terms the 'squanderers' as the 'associates of devil' (the Qur'an 17:27). This certainly has important implications (at least for the followers) for a consumption pattern that is compatible with sustainable environment. 


\section{POLICY SUGGESTIONS, LIMITATIONS AND SCOPE FOR FUTURE RESEARCH}

The goal of continuous and positive economic growth is not sustainable if that growth is reducing the ecological capital. There is a need to contemporize the growth perspective with eco-sustainability and it must have strong ethical foundation. Ethics and law can work hand in hand to ensure a well-functioning market. The government may introduce some incentives for organization who would promote environment friendly practices beyond the legally required level.

One problem with enforcing ethical standard is that it may be difficult to evaluate the impact of ethics policies. Since still there are substantial differences among societies with regards to ethical standards, a single evaluation method is probably not adequate. Case studies, logical reasoning and data-based empirical approaches all have their advantages and disadvantages. However a flexible combination of these methods may help to get a better picture. Some suitable proxies or instruments can be used to evaluate the impacts of ethical constraints.

The international codes of conduct for business should be more specific and in addition to that there should be effective 'non-discriminatory' enforcement mechanism. In academic and professional training more focus should be given on ethics. Sustainability requires the reduction of consumption and ethical standards can play a very important role here. There should be innovative ways to encourage less consumption. For example: the utilities' bills should contain instructions of the ways to reduce usage.

Though ethics is one of the most important issues, it should not be analyzed in isolation of other factors causing environmental problems. Future research should focus on how to formally incorporate ethics in standard economics model of various forms. Policies should be designed incorporating various community level issues since one set of policies may not be the best for all societies. Also, more research is required in the field of commercial ethics.

\section{REFERENCES}

Azqueta Dand Delacámara G. 2005. Ethics, Economics and Environmental Management. Department of Economic Analysis, University of Alcalá.

Barry, Brian. Liberty and Justice: Essays in Political Theory 2. Oxford University Press. 1991.

Krishnan, Rajaram; Harris, J M; Goodwin, N R edited, 1995. A Survey of Ecological Economics. Island Press.

Rothschild, K.W. (1993) Ethics and Economic Theory: Ideas, Models, Dilemmas, Aldershot: Edward Elgar.

Shrader-Frechette, Kristin, 2002. Environmental Justice: Creating Equality, Reclaiming Democracy. Oxford University Press.

Stern, Nicholas, 2007. Climate Change, Ethics and the Economics of the Global Deal.

Stiglitz, J E. 2003. Ethics, Market and Government Failure and Globalization.

Van Staveren, I. (2001) The Values of Economics: An Aristotelian Perspective, London: Routledge.

Yeager, L.B. (2001) Ethics as Social Science: The Moral Philosophy of Social Cooperation, Cheltenham: Edward Elgar.

$$
--0 \text {-- }
$$

